\title{
Pengembangan Media Pembelajaran Dakon Bilangan Pada Pembelajaran Matematika: Konsep FPB Dan KPK Siswa kelas IV Sekolah Dasar
}

\author{
Komariah $^{1}$ \\ ${ }^{1}$ SDN 98/X Rantau Indah, Jambi, Indonesia
}

\begin{tabular}{l}
\hline \hline Article Info \\
\hline Article history: \\
Received Mei 10, 2020 \\
Revised Mei 18, 2020 \\
Accepted Mei 28, 2020 \\
\hline
\end{tabular}

Keywords:

Matematika

Media Pembelajaran

Sekolah Dasar

\begin{abstract}
ABSTRAK
Tujuan Penelitian: Penelitian ini bertujuan untuk mengetahui prosedur pengembangan model Hannafin \& Peck, mengetahui kevalidan media, mengetahui kepraktisan media, dan mengetahui keefektifan media pembelajaran pada materi KPK dan FPB di kelas IV Sekolah Dasar.

Metodologi: Tahap penelitian ini menggunakan model pengembangan Hannafin \& Peck dengan subjek penelitian siswa kelas IV SD Negeri 98/X Rantau Indah. Instrumen pengumpulan data yang digunakan adalah instrumen kevalidan, kepraktisan dan instrumen keefektifan.

Temuan Utama: Hasil penelitian ini berupa prosedur pengembangan yang menghasilkan sebuah produk berupa media dakon bilangan yang valid, praktis dan efektif. Hasil validasi media memperoleh persentase keseluruhan $97,69 \%$ dan validasi materi mendapat persentase keseluruhan 86,13\%. Untuk keefektifan media termasuk pada klasifikasi tinggi dengan nilai 0,702 dan media dakon bilangan dinyatakan efektif. Hasil dari angket respon guru memperoleh persentase keseluruhan $90 \%$ dan respon siswa memperoleh persentase $91,68 \%$.
\end{abstract}

Aplikasi dalam Penelitian: Pengembangan media pembelajaran sangat penting dilakukan agar terciptanya pembelajaran yang menarik siswa.

Keterbarauan: Keterbaruan dalam penelitian ini adalah produk untuk media pembelajaran matematika untuk siswa sekolah dasar.

Copyright $@ 2020$ Cahaya Ilmu Cendekia Publisher. All rights reserved.

\section{Corresponding Author:}

Komariah

SDN 98/X Rantau Indah, Jambi, Indonesia

Email: komariah@gmail.co.id

\section{PENDAHULUAN}

Media pembelajaran sangat diperlukan dalam setiap mata pelajaran terutama pada mata pelajaran matematika yang bersifat abstrak. Siswa sekolah dasar usia (7-12 tahun) masih berada pada tahap operasional konkret [1]. Dimana siswa pada usia ini masih belajar menggunakan hal-hal yang nyata. Untuk itu guru dalam pembelajarannya terkhusus pada pelajaran matematika perlu menggunakan alat bantu berupa media pembelajaran supaya tujuan pembelajaran dapat tercapai dengan baik.

Melalui observasi awal yang dilakukan oleh peneliti di kelas IV SD Negeri 98/X Rantau Indah. Ditemukan fakta lapangan bahwa proses pembelajaran yang dilaksanakan belum sesuai dengan yang diharapkan disebabkan kurangnya penggunaan media pembelajaran. Selain itu, beberapa siswa juga mengalami kesulitan belajar matematika terkhususnya materi FPB dan KPK. Melalui pretest yang telah diberikan kepada 25 siswa tidak ada satupun yang mendapat nilai mencapai kriteria ketuntasan minimum. Adapun kriteria ketuntasan minimum yang ditetapkan ialah 63. Melalui permasalahan di atas, untuk itu perlu adanya penggunaan media pembelajaran pada materi FPB dan KPK. Media tersebut berupa dakon bilangan. 
Menurut Pitajeng. Dakon bilangan dapat dipakai untuk membantu anak belajar konsep bilangan prima dan menentukan bilangan prima, menentukan faktor-faktor pembagi suatu bilangan, menentukan kelipatan suatu bilangan, menentukan faktor pembagi persekutuan atau kelipatan persekutuan dua bilangan atau lebih, serta mencari FPB dan KPK dari dua bilangan atau lebih [2]

Berlandaskan dari pendapat Pitajeng tersebut maka dakon bilangan sesuai untuk digunakan dalam kegiatan pembelajaran khususnya pada materi FPB dan KPK. Karena dapat membantu siswa mencari FPB dan KPK dari dua bilangan, akan tetapi dakon bilangan konvensional yang telah ada kondisinya masih kurang menarik, kurang fleksibel untuk dibawa karena ukurannya yang besar dan tidak tahan lama, sehingga sangat penting adanya pengembangan terhadap media tersebut. Melalui latar belakang di atas maka peneliti tertarik untuk mengembangkan media dakon bilangan untuk materi FPB dan KPK. Alasan memilih pengembangan media ini karena dengan adanya pengembangan ini dapat menghadirkan media pembelajaran matematika yang praktis dan dapat melatih siswa memahami konsep FPB dan KPK.

Dari uraian latar belakang di atas peneliti tertarik untuk melakukan pengembangan dengan judul "Pengembangan Media Dakon Bilangan Pada Pembelajaran Matematika Untuk Melatih Pemahaman Konsep Materi FPB dan KPK Siswa Kelas IV Sekolah Dasar”.

\section{METODE PENELITIAN}

\section{Model Pengembangan}

Penelitian ini merupakan jenis penelitian pengembangan (research and Development). Penelitian ini menggunakan model pengembangan Hannafin dan Peck. Model ini terdiri dari tiga tahapan pengembangan.

\section{Prosedur Pengembangan}

Adapun prosedur yang akan dilaksanakan dalam pengembangan ini adalah penilaian kebutuhan, desain, pengembangan dan implementasi serta evaluasi dan revisi.

\section{Subjek Uji Coba}

Pada uji coba pemakaian yang menjadi subjek uji coba adalah siswa kelas IV Sekolah Dasar Negeri 198/1 Pasar Baru.

\section{Teknik Analisis Data}

Analisis Data Hasil Validasi

Data hasil validitas yang diperoleh, dianalisis menggunakan skala likert yang dibuat dalam tabel berikut, selanjutnya dicari persentase nilai dengan menggunakan rumus [3], sebagai berikut:

Tabel 1. Pedoman Penilaian Skor Validasi

\begin{tabular}{lc}
\hline Data Kualitatif & Skor \\
\hline Sangat sesuai (SS) & 5 \\
Sesuai (S) & 4 \\
Kurang sesuai (KS) & 3 \\
Tidak sesuai (TS) & 2 \\
Sangat tidak sesuai (STS) & 1 \\
\hline
\end{tabular}

Analisis data kuantitatif menggunakan rumus persentase untuk menghitung persentase dari masingmasing subjek yaitu :

Persentase $=\frac{\sum x}{S M 1} \mathrm{X} 100$

Keterangan $=$

$\sum x=$ Jumlah Skor

$M S I=$ Maksimal Skor Ideal

Selanjutnya untuk menghitung persentase keseluruhan subjek yaitu:

$\mathrm{P}=\mathrm{F}: \mathrm{N}$

Keterangan:

$\mathrm{F}=$ Jumlah persentase keseluruhan subjek

$\mathrm{N}$ : Banyak subjek

Setelah persentase keseluruhan kevalidan diperoleh ditetapkan kriteria [4], seperti pada tabel berikut:

Pengembangan Media Pembelajaran Dakon Bilangan Pada Pembelajaran Matematika... (Komariah) 
Tabel 2. Range Persentase dan Kriteria Kualitatif Kevalidan

\begin{tabular}{lll}
\hline Tingkat Pencapaian & Kualifikasi & Keterangan \\
\hline $90 \%-100 \%$ & Sangat baik & Tidak perlu direvsi \\
$75 \%-89 \%$ & Baik & Direvisi seperlunya \\
$65 \%-74 \%$ & Cukup & Cukup banyak revisi \\
$55 \%-64 \%$ & Kurang & Banyk direvisi \\
\hline $0-54 \%$ & Sangat kurang & Direvisi Total \\
\hline
\end{tabular}

\section{Analisis Angket Kepraktisan}

Analisis data kuantitatif menggunakan rumus persentase untuk menghitung persentase dari masingmasing subjek yaitu :

Persentase $=\frac{\sum x}{S M 1} \mathrm{X} 100$

Keterangan $=$

$\sum x=$ Jumlah Skor

$M S I=$ Maksimal Skor Ideal

Selanjutnya untuk menghitung persentase keseluruhan subjek yaitu:

$\mathrm{P}=\mathrm{F}: \mathrm{N}$

Keterangan:

$\mathrm{F}=$ Jumlah persentase keseluruhan subjek

$\mathrm{N}$ : Banyak subjek

Setelah persentase kepraktisan diperoleh, ditetapkan kriteria seperti pada tabel berikut:

Tabel 3. Range Persentase Dan Kriteria Kualitatif Kepraktisan

\begin{tabular}{lll}
\hline Tingkat Pencapaian & Kualifikasi & Keterangan \\
\hline $90 \%-100 \%$ & Sangat baik & Tidak perlu direvsi \\
$75 \%-89 \%$ & Baik & Direvisi seperlunya \\
$65 \%-74 \%$ & Cukup & Cukup banyak revisi \\
$55 \%-64 \%$ & Kurang & Banyk direvisi \\
$0-54 \%$ & Sangat kurang & Direvisi Total \\
\hline
\end{tabular}

\section{Analisis keefektifan}

Untuk keefektifan dilihat dari peningkatan hasil belajar siswa ini dapat dihitung dengan menggunakan $\mathrm{N}$-Gain berdasarkan nilai pretest dan post-test [5]

$\mathrm{g}=\frac{S_{\text {pos }}-S_{\text {pre }}}{S_{\text {maks }}-S_{\text {pre }}}$

Keterangan:

$S_{p o s}=$ Rata-rata skor post-test

$S_{\text {pre }}=$ Rata-rata skor pretest

$S_{\text {maks }}=$ Rata-rata skor maksimal

Berikut interprestasi table klasifikasi nilai Gain

\begin{tabular}{cc} 
Tabel 4. Kriteria Gain Ternormalisasi \\
\hline Nilai Gain & Klasifikasi \\
\hline Nilai Gain $\geq 0,7$ & Tinggi \\
$0,7>(N$ - gain $) \geq 0,30$ & Sedang \\
Nilai Gain $\leq 0,3$ & Rendah \\
\hline
\end{tabular}




\section{HASIL DAN PEMBAHASAN}

Pembahasan dalam penelitian ini dilakukan melalui hasil dari observasi dan wawancara. Adapun hasil observasi dan wawancara yag dilakukan di kelas IV sekolah dasar menunjukkan bahwa siswa mengalami kesulitan memahami materi KPK dan FPB, guru tidak meggunakan media pembelajaran serta kurangnya ketersedian media pembelajaran khususnya matematika. Dalam proses penelitian data hasil validasi ahli media dan materi, respon siswa dan guru serta hasil belajar siswa menjadi data penguat dalam penelitian ini[6]. Data yang diperoleh ialah data kuantitatif dan kualitatif. Data kuantitatif diperoleh dari skor yang diperoleh dari pengisian angket oleh validator saat melaksanakan validasi, angket respon guru dan siswa dan hasil belajar yang diperoleh oleh siswa sebelum dan sesudah menggunakan dakon bilangan. Skor yang diperoleh dicari persentase masing-masing subjek dan persentase keseluruhan untuk mengetahui tingkat kevalidan, kepraktisan media. Untuk melihat keefektifan media dakon bilangan diperoleh dari hasil peningkatan pretest dan post-test. Data kualitatif diperoleh dari analisis pernyataan yang diajukan dan komentar dan saran yang diberikan oleh validator [7]. Proses pengembangan media dakon bilangan dilakukan dengan menggunakan model Hannafin \& Peck. Model Hannafin \& Peck adalah model yang memiliki prosedur kerja yang sistematis yang terarah sehingga dapat terencana dengan baik [8].

Berdasarkan validasi yang dilakukan media dakon bilangan dinyatakan sangat valid dan layak untuk diujicobakan dengan persentase keseluruhan 97,69\% termasuk kualifikasi sangat baik oleh ahli media dan persentase keseluruhan 86,13 termasuk kualifikasi baik oleh ahli materi. Media dakon bilangan ini setelah dinyatakan valid kemudian dilakukan ujicoba kepada siswa kelas IV sekolah dasar melalui ujicoba kelompok kecil dan kelompok besar. Ujicoba ini untuk melihat seberapa efektifnya media dakon bilangan ini. Keefektifan ini dilihat melalui peningkatan hasil pretest dan posttest sebesar 0,702 dan termasuk klasifikasi tinggi. Pada tahap ini peneliti juga memberikan angket kepada siswa dan guru untuk mengetahui respon dari guru dan siswa setelah menggunakan dakon bilangan[9]. Hasil dari respon siswa dan guru ini digunakan untuk melihat seberapa praktis media dakon bilangan. Adapun hasil yang diperoleh melalui respon siswa diperoleh persentase keseluruhan 91,68 \% termasuk kualifikasi sangat baik dan respon guru memperoleh persentase keseluruhan $90 \%$ termasuk kualifikasi sangat baik.

\section{KESIMPULAN}

Melalui hasil penelitian dan pembahasan yang telah dilakukan, maka dapat disimpulkan bahwa penelitian ini mengetahui prosedur pembuatan produk dengan hasil produk berupa media dakon bilangan. Penelitian ini mengetahui kevalidan media memperoleh persentase keseluruhan 97,69 \% termasuk kualifikasi sangat baik dan persentase keseluruhan untuk kevalidan materi adalah 86,13\% dan termasuk kualifikasi baik. Penelitian ini juga mengetahui kepraktisan media melalui angket respon guru dengan persentase keseluruhan yaitu $90 \%$ dan respon siswa persentase keseluruhan 91,68 \% keduanya termasuk kualifikasi sangat baik dan dinyatakan praktis. Selain itu penelitian ini mengetahui keefektifan media melalui hasil belajar siswa dengan melihat peningkatan hasil pretest dan posttest yaitu 0,702 dan termasuk klasifikasi tinggi, berdasarkan hasil ini media dakon bilangan dinyatakan efektif.

\section{UCAPAN TERIMA KASIH}

Terimakaish kepada seluruh responden yang telah bersedia, sehingga penelitian ini dapat saya selesaikan. Serta semua elemen yang telah ikut berpartisipasi, saya ucapkan terimakasih

\section{REFERENSI}

[1] Husamah \& Setyaningrum, Y. 2013. Desain Pembelajaran Berbasis Pencapaian Kompetensi. Jakarta: Prestasi Pustakarya.

[2] Pitajeng. 2006. Pembelajaran Matematika yang Menyenangkan. Jakarta: Depdiknas.

[3] Widoyoko, E.P. 2017. Teknik Penyusunan Instrumen Penelitian. Yogyakarta: Pustaka Pelajar

[4] Tegeh, M. I.N.J \& Ketut, P. 2014. Model Penelitian Pengembangan. Yogyakarta: Graha Ilmu.

[5] Lukman \& Ishartiwi. 2014. Pengembangan Bahan Ajar dengan Model Mind Map Untuk Pembelajaran Ilmu Pengetahuan Sosial SMP. Jurnal Inovasi Teknologi Pendidikan, Volume 1 - Nomor 2, 2014. (online) luxssains@yahoo.co.id, diakses 28 Februari 2018.

[6] Amin, A. 2005. Pengembangan Media Permainan Dakonmatika pada Materi Faktor Persekutuan Terbesar (FPB) dan Kelipatan Persekutuan Terkecil (KPK) bagi Siswa Kelas IV Baitur Rohim. Skripsi. UIN Sunan Ampel. Surabaya.

[7] Arikunto, S. (2009). Dasar-dasar Evaluasi Pendidikan (Edisi Revisi). Jakarta: Bumi Aksara.

[8] Asyhar, R \& Khairanil. 2010. Media Pembelajaran Sekolah Dasar. Jakarta:Gaung Persada (GP) Press Jakarta.

[9] Asyhar, R. 2011. Kreatif Mengembangkan Media Pembelajaran. Jakarta:Gaung Persada. 